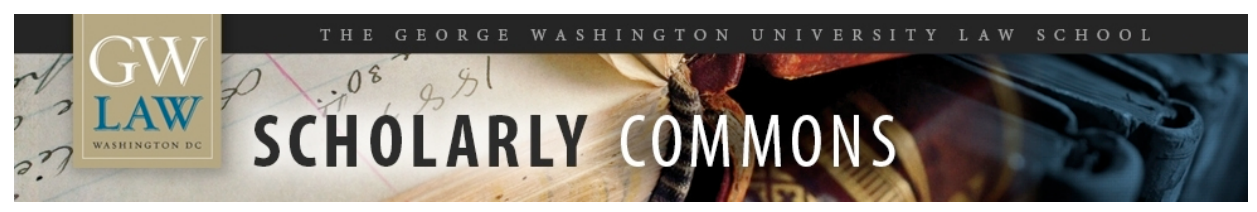

\title{
What a Difference a Year Makes: The International Court of Justice's 2012 Jurisprudence
}

Sean D. Murphy

George Washington University Law School, smurphy@law.gwu.edu

Follow this and additional works at: https://scholarship.law.gwu.edu/faculty_publications

Part of the Law Commons

\section{Recommended Citation}

Sean D. Murphy, What a Difference a Year Makes: The International Court of Justice's 2012 Jurisprudence, Journal of International Dispute Resolution (forthcoming 2013).

This Article is brought to you for free and open access by the Faculty Scholarship at Scholarly Commons. It has been accepted for inclusion in GW Law Faculty Publications \& Other Works by an authorized administrator of Scholarly Commons. For more information, please contact spagel@law.gwu.edu. 


\title{
What a Difference a Y ear M akes: The International C ourt of J ustice's 2012 J urisprudence
}

\author{
Journal of International Dispute Resolution (forthcoming 2013)
}

\author{
Sean D. M urphy \\ Patricia Roberts Harris Research P rofessor of Law, George Washington U niversity \\ M ember, U.N. International Law Commission
}

A $n$ analysis of any particular decision of the International Court of Justice sometimes misses broader, cross-cutting themes that animate the Court's jurisprudence. This essay, prepared for an A pril 2013 symposium at the European University Institute, Robert Schuman Centre for A dvanced Studies, in Florence, explores a few of the themes that emerged from the Court's 2012 jurisprudence. With respect to sources of law, the Court's decisions confirm the enduring relevance of non-treaty sources of law, the enduring attraction of multilateral treaties for ascertaining customary rules, and the emergence of jus cogens as feature of the Court's jurisprudence, though perhaps more dazzling in theory than in practical application. Further, the Court's decisions highlight the continuing structural difficulty for international law and institutions in coping with redress for harm to individuals. In light of these themes, the essay concludes by suggesting some implications for the future codification and progressive development of international law.

I. Enduring Relevance of Customary International Law and General Principles of Law as Sources of International Law

The modern network of multilateral and bilateral treaties that span all sectors of international law can lead one to assume that when disputes arise between States there will inevitably be an international agreement relevant to the matter. Y et a survey of the Court's 2012 jurisprudence readily demonstrates the enduring relevance of customary international law and general principles of law. 
In J urisdictional Immunities of the State, ${ }^{1}$ there existed no treaty between Germany and Italy identifying the nature and scope of the immunity to be accorded to governments under national law. Germany was a party to the European Convention on State Immunity (European Convention), ${ }^{2}$ but Italy was not. Neither State had ratified the U.N. Convention on the J urisdictional Immunities of States and their Property (U.N. Convention) ${ }^{3}$ nor, in any event, had that treaty entered into force. Consequently, the Court decided the case using rules of customary international law, ${ }^{4}$ which resulted in an extensive analysis of national laws, judicial decisions on immunity and, as discussed in Section II, treaties as evidence of State practice.

Similarly, in Ahmadou Sadio Diallo, ${ }^{5}$ the Court had previously found that the Democratic Republic of the Congo (DRC) had violated Article 9 of the International Covenant on Civil and Political Rights ${ }^{6}$ and Article 6 of the African Charter of Human and Peoples' Rights. ${ }^{7} Y$ et neither those treaties nor any other treaty between the Republic of Guinea and the DRC contained a provision on the type and extent of remedy appropriate for the violations of human rights or on the evidence necessary to support a remedy. As a result, the Court had to probe the practice of a number of international courts and tribunals, including its own prior decisions and those of regional human rights courts and ad hoc claims commissions, to decide on issues such as the proper heads of damage, the nature and quantification of non-material injury, whether material damage may be awarded based on equitable considerations, whether compensation may be awarded for lost income, and whether post-judgment interest is appropriate. ${ }^{8}$ The Court's reliance on such a wide range of jurisprudence from other tribunals might be viewed as a counter-argument to concerns about the 'fragmentation' of international law, ${ }^{9}$ demonstrating the

\footnotetext{
${ }^{1}$ Jurisdictional Immunities of the State (Ger v It: Greece intervening), Judgment (3 February), [2012] ICJ, available at http://www.icj-cij.org/docket/files/143/16883.pdf.

${ }^{2}$ European Convention on State Immunity, 16 May 1972, 1495 UNTS 182, ETS No 74.

${ }^{3}$ UN Convention on Jurisdictional Immunities of States and Their Property, 2 December 2004, UN Doc A/RES/59/38, Annex (16 December 2004).

${ }^{4}$ Jurisdictional Immunities of the State (n 1), para 55.

${ }^{5}$ Ahmadou Sadio Diallo (Guinea v Dem Rep Congo), Judgment (19 June), [2012] ICJ para 3, available at http://www.icj-cij.org/docket/files/103/17044.pdf.

${ }^{6}$ International Covenant on Civil and Political Rights art 9, 16 December 1966, 999 UNTS 171.

${ }^{7}$ African Charter on Human and Peoples' Rights art 6, 27 June 1981, OAU Doc CAB/LEG/67/3 rev. 5, 21 ILM 58 (1982).

${ }^{8}$ Ahmadou Sadio Diallo (n 5), paras 13-15, 18, 24, 33, 40, 49, 56.

${ }^{9}$ See International Law Commission, 'Fragmentation of International Law: Difficulties Arising from the Diversification and Expansion of International Law' (Report of the Study Group of the International Law
} 
ability of international courts to engage in a cooperative trans-institutional dialogue. ${ }^{10}$ Indeed, J udge Greenwood in his Declaration, after noting the Court's use of jurisprudence from other courts and tribunals, declared:

International law is not a series of fragmented specialist and self-contained bodies of law, each of which functions in isolation from the others; it is a single, unified system of law and each international court can, and should, draw on the jurisprudence of other international courts and tribunals, even though it is not bound necessarily to come to the same conclusions. ${ }^{11}$

In the Territorial and M aritime Dispute case, the question of what maritime features were capable of being sovereign territory was decided on the basis of customary international law. ${ }^{12}$ The further question of which State was sovereign over those features also turned on application of customary international law to the acquisition of territory, including the principle of uti possidetis juris ${ }^{13}$ and the concept of effectivités through acts à titre de souverain. ${ }^{14}$ Although Colombia and Nicaragua's 1928 Treaty (the Barcenas-Esguerra Treaty) was a starting point for considering which State was sovereign, the Court ultimately concluded that the treaty did not conclusively answer that question because it did not clearly indicate which maritime features fell within the San A ndrés A rchipelago, thus necessitating reliance on other law. ${ }^{15}$ J udge A braham took the Court to task in his separate opinion for abandoning the treaty, arguing that 'difficulty' in interpreting a treaty is not a basis for setting it aside, ${ }^{16}$ but his concern apparently gained no traction with the Court. As for delimitation of the maritime boundary between the two States, Colombia was not a party to the U.N. Convention on the Law of the Sea, so the Court applied

\footnotetext{
Commission, finalized by Martti Koskenniemi, UN Doc A/CN.4/L.682 (13 April 2006), as corrected UN Doc A/CN.4/L.682/Corr.1 (11 August 2006)).

${ }^{10}$ See Ole Kristian Fauchald and André NollKaemper (eds), The Practice of International and National Courts and the (De-)Fragmentation of International Law (Hart Publishing 2012) 8; Suzannah Linton and Firew Kebede Tiba, 'The International Judge in an Age of Multiple International Courts and Tribunals' (2009) 9 Chi J Intl L 407.

${ }^{11}$ Ahmadou Sadio Diallo (n 5), Declaration of Judge Greenwood para 8, available at http://www.icjcij.org/docket/files/103/17050.pdf.

${ }^{12}$ Territorial and Maritime Dispute (Nicar v Colom), Judgment (19 November), [2012] ICJ para 26, available at http://www.icj-cij.org/docket/files/124/17164.pdf.

13 ibid para 57-65.

${ }^{14}$ ibid paras 66-84.

${ }^{15}$ ibid para 56.

${ }^{16}$ Territorial and Maritime Dispute (n 12), Separate Opinion of Judge Abraham paras 2-20, available at http://www.icj-cij.org/docket/files/124/17168.pdf.
} 
customary international law, ${ }^{17}$ including 'the principle that the land dominates the sea through the projection of the coasts or the coastal fronts' 18

Notwithstanding the enduring relevance of customary international law and general principles of law, it must also be said that where the Court has a binding treaty instrument before it that is directly relevant to the dispute, the Court gravitates to that instrument as the relevant source of law. In Obligation to Prosecute or Extradite, Belgium placed before the Court arguments based upon both the U.N. Convention against Torture and customary international law. ${ }^{19}$ As discussed further below, the Court set aside the customary international law arguments, purportedly on jurisdictional grounds, and instead based its decision on the multilateral treaty ratified by both Belgium and Senegal. ${ }^{20}$ Likewise, in the Advisory Opinion on Judgment $\mathrm{No}$. 2867 of the Administrative Tribunal of the International Labour Organization, the Court focused on interpreting and applying international instruments, principally the statute of the administrative tribunal whose decision was being challenged, ${ }^{21}$ as well as the underlying employment contract. ${ }^{22}$ Even so, in the course of its decision, the Court also relied upon certain general principles of international law, such as the principle favoring equality of access to present a claim or defense before a tribunal. ${ }^{23}$

\section{Enduring A ttraction of M ultilateral Treaties for A scertaining Customary Rules}

In determining the meaning of customary international law, the Court was often attracted to and relied upon longstanding multilateral treaty instruments as an expression of such norms, even though the treaties themselves were not binding upon the Parties before it. In doing so, the Court would sometimes note that the Parties themselves viewed the relevant treaty provisions as reflecting customary international law. ${ }^{24}$ Conversely, in some instances the Court noted the 'long

\footnotetext{
${ }^{17}$ Territorial and Maritime Dispute (n 12), para 137.

18 ibid para 140.

${ }^{19}$ Questions Relating to the Obligation to Prosecute or Extradite (Belg v Sen), Judgment (20 July), [2012] ICJ para 1, available at http://www.icj-cij.org/docket/files/144/17064.pdf.

${ }^{20}$ ibid para 55.

${ }^{21}$ See, e.g., Judgment No. 2867 of the Administrative Tribunal of the International Labour Organization (ILO), Advisory Opinion (1 February), [2012] ICJ para 21, available at http://www.icj-cij.org/docket/files/146/16871.pdf.

22 ibid para 76.

23 ibid paras 37, 39.

${ }^{24}$ See, e.g., Territorial and Maritime Dispute (n 12), para 138.
} 
and difficult discussions' that led to a recent multilateral treaty provision, suggesting that the provision - at least in its entirety - may not reflect settled customary international law. ${ }^{25}$

For example, in Jurisdictional Immunities of the State, the Court's discussion of the 'territorial tort' exception to sovereign immunity begins with a detailed consideration of the text of both Article 11 of the European Convention and Article 12 of the U.N. Convention on sovereign immunities, both of which contained a version of such an exception. ${ }^{26}$ The Court consulted those same conventions when considering whether immunity should be denied where the claims concerned serious violations of human rights law or the law of armed conflict, ${ }^{27}$ whether Italy's last resort argument was credible, ${ }^{28}$ and whether Italy was obliged to enforce decisions rendered in Greek courts. ${ }^{29}$ Judge Koroma in his separate opinion discussed the negotiating history of the U.N. Convention to demonstrate that a territorial tort exception could not cover acta jure imperii by armed forces during armed conflict. ${ }^{30}$

In the Territorial and Maritime Dispute case, the Court used the provisions of A rticles 74 and 83 of the U.N. Convention on the Law of the Sea (LOSC) as reflective of customary international law on the delimitation of the exclusive economic zone and continental shelf. ${ }^{31}$ Further, the Court held that LOSC A rticle 76(1), which defines the continental shelf as extending to the outer edge of the continental margin, constituted customary international law, though it saw no need to address the customary status of the remaining paragraphs of that article. Likewise, the Court used LOSC A rticle 121 when considering the legal régime of islands under customary international law. ${ }^{32}$ Judge $K$ eith in his Declaration focused considerably on the drafting history of the U.N. Convention on the Law of the Sea, regarding it as directly relevant to the methodology adopted by the Court in its maritime delimitation. ${ }^{33}$

\footnotetext{
${ }^{25}$ See, e.g., Jurisdictional Immunities of the State (n 1), paras 115-17.

${ }^{26}$ ibid paras 64-69.

27 ibid para 89.

28 ibid para 101.

29 ibid para 129.

${ }^{30}$ Jurisdictional Immunities of the State (n 1), Separate Opinion of Judge Koroma paras 6-7, available at http://www.icj-cij.org/docket/files/143/16885.pdf.

${ }^{31}$ Territorial and Maritime Dispute (n 12), paras 137-39.

32 ibid.

${ }^{33}$ Territorial and Maritime Dispute (n 12), Declaration of Judge Keith paras 4-8, available at http://www.icjcij.org/docket/files/124/17170.pdf.
} 
Although engaged in a customary international law analysis, the Court decided not to delimit the continental shelf between Nicaragua and Colombia beyond 200 nautical miles in part because the outer limits of Nicaragua's continental shelf had not yet been established through a Nicaraguan submission to the Commission on the Limits of the Continental Shelf under LOSC Article $76 .{ }^{34}$ As Judge Donoghue observed in her separate opinion, even though customary international law applied to the delimitation of the continental shelf as between Nicaragua and Colombia, the Court apparently refrained from such delimitation based upon Nicaragua's failure to pursue a procedural mechanism of a treaty, despite the fact Colombia - a non-party - had not yet become a party to that treaty. ${ }^{35}$ One wonders if the result would have been different if Colombia had been the A pplicant in the case or at least had not opposed delimitation beyond 200 nautical miles.

\section{J us Cogens - Dazzling in Theory; Disappearing in Practice}

Since its establishment almost seventy years ago, the International Court has only occasionally referred to jus cogens, which is defined in the Vienna Convention on the Law of Treaties as a rule 'accepted and recognized by the international community of States as a whole as a norm from which no derogation is permitted and which can be modified only by a subsequent norm of general international law having the same character. ${ }^{36} \mathrm{Y}$ et jus cogens featured in not just one but two of the Court's cases in 2012.

The Court expressly declared in O bligation to Prosecute or Extradite that 'the prohibition of torture is part of customary international law and it has become a peremptory norm (jus cogens). ${ }^{37}$ In so doing, the Court suggested the key components for identifying a peremptory norm: widespread practice of States refraining from the proscribed conduct; opinio juris by those States; codification of the prohibition in numerous international instruments of universal application; incorporation of the prohibition into the national law of almost all States; and regular

\footnotetext{
${ }^{34}$ Territorial and Maritime Dispute (n 12), paras 126-29.

${ }^{35}$ Territorial and Maritime Dispute (n 12), Separate Opinion of Judge Donoghue para 26, available at http://www.icj-cij.org/docket/files/124/17174.pdf.

${ }^{36}$ Vienna Convention on the Law of Treaties, May 23, 1969, art. 53, 1155 U.N.T.S. 331; see Military and Paramilitary Activities in and against Nicaragua (Nicar. v. U.S.), 1986 I.C.J. 14, 100, para. 190 (June 27); Armed Activities on the Territory of the Congo (New Application: 2002) (D.R.C. v. Rwanda), 2006 I.C.J. 6, 32, para. 64 (Feb. 3); Application of the Convention on Genocide (Bosnia-Herz. V. Serbia \& Mont.), 2007 I.C.J. 43, 161, para. 161 (Feb. 26).

${ }^{37}$ Obligation to Extradite or Prosecute (n 19), para 99.
} 
condemnation of such conduct in national and international fora. ${ }^{38}$ The Court's approach suggests that the identification of a norm as jus cogens is much like the identification of any customary rule of international law, al beit perhaps with an even greater degree of State practice. Though the Court refrained from expressly deciding as much in J urisdictional Immunities of the State, it was willing to entertain the possibility that 'the rules of the law of armed conflict which prohibit the murder of civilians in occupied territory, the deportation of civilian inhabitants to slave labour and the deportation of prisoners of war to slave labour are rules of jus cogens.' ${ }^{39}$

Even so, jus cogens had no real practical effect in the decisions where it arose. In Obligation to Prosecute or Extradite, the status of the prohibition on state-sponsored torture as jus cogens did not mean that Senegal's obligation to prosecute or extradite existed in the period prior to Senegal's adherence to the Convention against Torture. ${ }^{40}$ In other words, while Chad and its President Hissène Habré were prohibited in the 1980s from engaging in state-sponsored torture, the status of that prohibition as jus cogens did not by itself impose an obligation upon Senegal to prosecute or extradite Habré when the ousted former President subsequently arrived in that country; rather, the obligation only arose once the Convention entered into force for Senegal. Indeed, in that case nothing seemed to turn on the status of the norm as jus cogens.

Likewise, in Jurisdictional Immunities of the State, the Court accepted arguendo that many of the allegations in Italian courts amounted to violations of jus cogens. ${ }^{41}$ Still, the Court concluded that rules on the scope and extent of jurisdiction and immunity in national courts are not themselves derogations from jus cogens and that the severity of a violation of international law is not germane to the existence of immunity from national jurisdiction; accordingly, customary international law on State immunity is not affected even if the claims before national courts relate to a State's alleged violations of jus cogens. ${ }^{42}$ Similar reasoning precluded the denial of immunity notwithstanding allegations of serious violations of international human rights law or the international law of armed conflict. ${ }^{43}$ That outcome was troubling to Judge Cançado Trindade, who lamented the 'abyss separating my own position from that of the Court's

\footnotetext{
${ }^{38}$ ibid.

${ }^{39}$ Jurisdictional Immunities of the State (n 1), para 93.

${ }^{40}$ Obligation to Extradite or Prosecute ( $\left.\mathrm{n} 19\right)$, para 100.

${ }^{41}$ Jurisdictional Immunities of the State (n 1), para 93.

${ }^{42}$ ibid para 97.

${ }^{43}$ ibid para 91.
} 
majority' and that 'without the primacy of jus cogens, international law would have a grim future. ${ }^{44}$ Judge Cançado Trindade criticized not only the Court but also States for 'olympically ignor[ing] the incidence of jus cogens' when they drafted the U.N. Convention. ${ }^{45}$

$Y$ et given that the content and effects of jus cogens turns, presumably, in large part on the views of the Court as a whole and on the views of States, the overall effect of J udge Cançado Trindade's lengthy dissenting opinion may be to establish that his views on jus cogens are idiosyncratic. Even the other two dissenting judges did not follow Judge Cançado Trindade's reasoning. Judge $Y$ usuf was clear that the core issue was not that 'each time there is a claim for reparation of breaches of international humanitarian law or human rights, the domestic courts of the State where the breaches had been committed, are entitled to set aside the immunity of the State responsible for such breaches.' ${ }^{46}$ Doing so might 'result in countless lawsuits that may overwhelm both the judicial system of the State where the claims are made and the governmental machinery of the responsible State. ${ }^{47}$ Similarly, Italy's ad hoc judge, Giorgio Gaja, found that 'the nature of the obligation under international law which is at the origin of the claim does not per se provide sufficient evidence that jurisdiction may be exercised over foreign States in case of a claim for reparation for the breach of an obligation under a peremptory norm wherever committed.' ${ }^{48}$ Both Judge Y usuf's and Judge Gaja's positions were more nuanced than that of J udge Cançado Trindade, viewing the severity of the violation as one factor that might support application of an exception to immunity.

\section{For Harm to Persons, Contemporary Rules But Traditional Processes}

Although international law seeks to protect persons from serious harms by governments, it often provides weak and inefficient mechanisms for them to pursue claims, and that fact was evident in a few of the Court's 2012 decisions. As J udge Cançado Trindade observed in one of his separate opinions, although 'States have lost the monopoly of international legal personality a

\footnotetext{
${ }^{44}$ Jurisdictional Immunities of the State (n 1), Dissenting Opinion of Judge Cançado Trindade para 288, available at http://www.icj-cij.org/docket/files/143/16891.pdf.

45 ibid para 224.

46 Jurisdictional Immunities of the State (n 1), Dissenting Opinion of Judge Yusuf para 54, available at http://www.icj-cij.org/docket/files/143/16893.pdf.

47 ibid.

48 Jurisdictional Immunities of the State (n 1), Dissenting Opinion of Judge Ad Hoc Gaja para 11, available at http://www.icj-cij.org/docket/files/143/16895.pdf (emphasis added).
} 
long time ago,' the 'insufficiency, if not artificiality, of the exclusively inter-State outlook of the procedures before the ICJ has become manifest, in the light of the very nature of some of the contentious cases submitted to it ... [and] by the exercise of its advisory function .... . ${ }^{49}$ Three of the Court's 2012 decisions provide different vantage points for this issue: private claims advanced in national courts to vindicate a violation of international law run into immunities; ${ }^{50}$ a private claim advanced before an international administrative tribunal to vindicate a violation of international law; ${ }^{51}$ and private claims advanced through diplomatic protection by the individual's State to vindicate a violation of international law. ${ }^{52}$

In Jurisdictional Immunities of the State, of course, may be seen the phenomenon of private claims based on international law being advanced in national courts. In that instance, there was common ground between the two States and the Court that internationally wrongful acts were committed against Italian nationals by German military forces during the latter part of W orld War II. Indeed, the Court observed that 'Germany has fully acknowledged the "untold suffering inflicted on Italian men and women in particular during massacres, and on former Italian military internees." ${ }^{53}$ As a result, the arguments presented by Italian nationals in Italian courts for violations of international law on the merits had considerable force. Even so, the Court's judgment closed the door on such claims, due to the immunity to which the Government of Germany was entitled.

The recognition of such immunity is not surprising, especially in the context of the governmental conduct at issue - action by military units in time of war - that falls squarely within the realm of acta jure imperii. ${ }^{54}$ Nevertheless, that result made for a disturbing juxtaposition between the general agreement that wrongful acts had occurred and the lack of a forum where the victims could vindicate their claims. Although the Court said it was both surprised and regretful that Germany to date had denied compensation to the claimants, the Court found 'no basis in the State practice from which customary international law is derived that

\footnotetext{
${ }^{49}$ Ahmadou Sadio Diallo (n 5), Separate Opinion of Judge Cançado Trindade paras 11-12, available at http://www.icj-cij.org/docket/files/103/17046.pdf.

${ }^{50}$ Jurisdictional Immunities of the State (n 1).

${ }^{51}$ Judgment No. 2867 of the Administrative Tribunal of the ILO (n 21).

${ }^{52}$ Ahmadou Sadio Diallo (n 5).

53 Jurisdictional Immunities of the State (n 1), para 52.

${ }^{54}$ ibid para 60.
} 
international law makes the entitlement of a State to immunity dependent upon the existence of effective alternative means of securing redress. ${ }^{55}$ The most the Court could do was to note that the claims of Italian nationals 'could be the subject of further negotiation involving the two States concerned, with a view to resolving the issue. ${ }^{56}$

Judge B ennouna voted in favor of the Court's judgment, but explained that his support was predicated on an expectation that Germany would meet its responsibility. ${ }^{57}$ For Judge Bennouna, where a State acknowledges its responsibility for unlawful acts and fails to then provide a remedy, it loses the benefit of immunity in foreign national jurisdictions. ${ }^{58}$ Thus, 'if Germany were to close all doors to such settlement ... then the question of lifting its immunity before foreign courts in respect of those same wrongful acts could legitimately be raised again. ${ }^{59}$ Judge $Y$ usuf was of the same mind, though his displeasure with the Court's failure to think through the legal implications of all the doors being closed prompted him to dissent. ${ }^{60}$ The same concern animated Judge Cançado Trindade's dissent, which essentially took the position that a breach of international law and the ensuing compliance with the duty of reparation was part of an indissoluble whole; they should not conceptually be differentiated as primary and secondary obligations. ${ }^{61}$ Further, that indissoluble whole could not be broken by a claim of State immunity, a point he reiterated in Ahmadou Sadio Diallo. ${ }^{62} \mathrm{~N}$ evertheless, his view did not attract support from the Court as a whole.

The phenomenon of a private claim being advanced before an international administrative tribunal to vindicate a violation of international law arose in the A dvisory O pinion on J udgment No. 2867 of the Administrative Tribunal of the ILO. There, the Court was placed in the awkward position of essentially deciding the validity of the claim by M s. Saez García against the International Fund for A gricultural Development (IFAD), even though Ms. García was

\footnotetext{
55 ibid para 101.

${ }^{56}$ ibid para 104.

57 Jurisdictional Immunities of the State (n 1), Separate Opinion of Judge Bennouna para 13, available at http://www.icj-cij.org/docket/files/143/16889.pdf.

58 ibid para 15.

59 ibid para 25.

${ }^{60}$ Dissenting Opinion of Judge Yusuf (n 46), para 17.

${ }^{61}$ Dissenting Opinion of Judge Cançado Trindade ( $n$ 44), para 294.

${ }^{62}$ Separate Opinion of Judge Cançado Trindade (n 49), para 35.
} 
precluded from communicating directly with the Court. ${ }^{63}$ Article XII of the Statute of the Administrative Tribunal of the International Labor Organization (ILOAT) allowed IFAD to challenge decisions rendered by the ILOAT in M s. García's favor by referring the matter to the Court, but provided no means for direct participation by Ms. García. ${ }^{64}$ Instead, the Court's Registrar informed M s. García that any communications that she wished to convey to the Court had to be done through IFAD, the entity that allegedly harmed her. ${ }^{65}$ To help ameliorate the problem, the Registrar requested that the General Counsel of IFAD 'provide to the Court, without any control being exercised over their content, any communications from Ms Saez García relating to the request for an advisory opinion that she might wish to submit to it. ${ }^{\prime 66}$ Even so, the process encountered difficulties, including an initial failure of IFAD to transmit to the Court M s. García's communications. ${ }^{67}$

The peculiarity and even perversity of a victim having to communicate with a court only through the alleged perpetrator of the harm was not lost on the judges. The Court appears to have seriously considered declining to issue the advisory opinion, due to concerns regarding inequality of access to, and inequality in the proceedings before, the Court. ${ }^{68}$ Among other things, the Court noted Article 14(1) of the International Covenant on Civil and Political Rights and associated comments by the Human Rights Committee. ${ }^{69}$ Both Judges Cançado Trindade and Greenwood commented on this concern, with the former suggesting an erosion of the 'interState outlook' of adjudication at the IC ${ }^{70}$ and the latter asserting that problems existed both from granting only IFAD the ability to initiate an ICJ proceeding and from then denying Ms. García direct access to the Court. ${ }^{71}$ For J udge Greenwood, 'the inequality of access which exists at present cannot be allowed to persist into the future. ${ }^{72}$ Ultimately, the Court did answer the

\footnotetext{
${ }^{63}$ See Judgment No. 2867 of the Administrative Tribunal of the ILO (n 21), Separate Opinion of Judge Cançado Trindade para 20, available at http://www.icj-cij.org/docket/files/146/16873.pdf.

${ }^{64}$ Judgment No. 2867 of the Administrative Tribunal of the ILO (n 21), para 1.

65 ibid para 10.

${ }^{66}$ ibid para 12.

67 ibid para 46.

${ }^{68}$ ibid paras 33-48.

${ }^{69}$ ibid para 39.

${ }^{70}$ Separate Opinion of Judge Cançado Trindade (n 63), paras 76-81.

${ }^{71}$ Judgment No. 2867 of the Administrative Tribunal of the ILO (n 21), Declaration of Judge Greenwood paras 3-4, available at http://www.icj-cij.org/docket/files/146/16875.pdf.

72 ibid para 3.
} 
question placed before it, ${ }^{73}$ but only in a manner that favored M s. García; one wonders whether an advisory opinion disfavoring the person would have issued given the Court's concerns about an inequality of arms.

Ahmadou Sadio Diallo demonstrates the phenomenon of a State using diplomatic protection to advance a claim on behalf of one of its nationals to vindicate a violation of international law. As Judge Greenwood observed at the outset of his declaration, although Guinea brought the case to the Court, it was 'in substance about the human rights of $\mathrm{Mr}$. Diallo.' ${ }^{74}$ There is no express indication in the judgment that M r. Diallo had any difficulty in providing information to his government for the purpose of securing compensation for the deprivation of his human rights. At the same time, the decision makes clear that Guinea produced no specific evidence of non-material injury to $\mathrm{Mr}$. Diallo, ${ }^{75}$ produced no evidence about $\mathrm{Mr}$. Diallo's inability to transport personal property from the $\mathrm{DRC}{ }^{76}$ produced no evidence of high-value items in Mr. Diallo's apartment, ${ }^{77}$ produced no evidence regarding alleged assets in bank accounts, ${ }^{78}$ and produced no evidence of $\mathrm{Mr}$ r. Diallo's monthly earnings that were lost due to his detention or expulsion. ${ }^{79}$ The failure to prove such losses largely explains why the Court, after 14 years of litigation involving three different phases, awarded compensation of just US\$95,000 - an amount that no doubt was dwarfed by the litigation expenses of the two States. ${ }^{80}$

One cannot definitively say that the amount of compensation awarded would have been any different if Mr. Diallo was able to represent himself directly before the Court. $Y$ et it is probably the case that an aggrieved individual is motivated to present his case more zealously than is his government; indeed, a government's interest in pursuing litigation involving a neighboring State, with whom it has a complex political relationship, is not the same as the interest of an individual, especially one who likely intends to have no future relationship with

\footnotetext{
${ }_{73}^{73}$ Judgment No. 2867 of the Administrative Tribunal of the ILO (n 21), para 100.

${ }^{74}$ Ahmadou Sadio Diallo ( $\mathrm{n} 5$ ), Declaration of Judge Greenwood para 1, available at http://www.icjcij.org/docket/files/103/17050.pdf.

${ }^{75}$ Ahmadou Sadio Diallo (n 5), para 19.

76 ibid para 31.

${ }_{78}^{77}$ ibid para 34.

${ }_{78}^{78}$ ibid para 35.

${ }^{79}$ ibid paras 41, 49.

${ }^{80}$ ibid para 56.
} 
that other State. Had Mr. Diallo, through his own lawyers, appeared before the Court, it is possible that different tactical choices would have been made: they might have submitted more than just a single pleading on damages; they might have produced more evidence on the material and non-material damages, including expert opinions; and they might have implored the Court to appoint a fact-finding expert of its own, as was done in the Corfu Channel case. ${ }^{81}$

\section{Implications for Future E fforts at Codifying International Law}

The Court's jurisprudence has implications well beyond the binding effects upon the States that appear before it, especially given the Court's stature as the judicial organ of the United Nations. Although the Court is careful to indicate that its decisions are limited to the facts of the cases before it, in a world of limited international jurisprudence it is inevitable that the Court's legal reasoning will impact in new and different ways the development of international law. One effect may be seen in the work of the International Law Commission, which pays close attention to the Court's jurisprudence when engaging in the Commission's mandate to codify and progressively develop international law. Three current projects of the Commission may well be affected by the Court's 2012 jurisprudence.

First, the Commission is currently studying customary international law on the immunity of State officials from the national criminal jurisdiction of another State, a topic that was included in the Commission's agenda in 2007, and is now moving forward under the stewardship of Concepción Escobar Hernández (Spain) as Special Rapporteur. ${ }^{82}$ Earlier decisions of the Court are directly relevant to this topic, such as the 2007 judgment in Certain Questions of M utual Assistance in Criminal Matters ${ }^{83}$ and the 2002 Arrest Warrant judgment, ${ }^{84}$ but it seems likely that the 2012 judgment on J urisdictional Immunities of the State will also be influential. To be sure, the Court was careful in J urisdictional Immunities of the State to say that it was only assessing immunity of a State, not immunity of officials, ${ }^{85}$ but the Court also repeatedly referenced customary international law relating to immunity of officials when construing

\footnotetext{
${ }^{81}$ Corfu Channel case (UK v Alb), Judgment (9 April), [1949] ICJ Rep 4, 9.

82 Report of the International Law Commission para 84, 64th Sess, 7 May-1 June, 2 July-3 August, 2012, UN Doc A/67/10; GAOR, 67th Sess, Supp No 10 (2012).

${ }^{83}$ Certain Questions of Mutual Assistance in Criminal Matters (Djib v Fr), Judgment (4 June), [2008] ICJ Rep 177, para 188.

${ }_{85}^{84}$ Arrest Warrant of 11 April 2000 (Dem Rep Congo v Belg), Judgment (14 February), [2002] ICJ Rep 3, paras 51-58.

${ }^{85}$ Jurisdictional Immunities of the States (n 1), para 91.
} 
customary international law relating to immunity of States, thereby suggesting that the two bodies of law - if not identical - are at least linked in important ways. As such, one might envisage some aspects of the Court's 2012 judgment affecting the Commission's approach to immunity of officials.

For example, as noted above, the Court found that 'customary international law does not treat a State's entitlement to immunity as dependent upon the gravity of the act of which it is accused or the peremptory nature of the rule which it is alleged to have violated. ${ }^{86}$ That conclusion would seem relevant as well with respect to the immunity of officials. Indeed, if an allegation that the State's acts violated a norm of jus cogens was not seen as altering a norm on State immunity from national jurisdiction because the two norms address different concerns, ${ }^{87}$ then it is not readily apparent why the outcome should be different in the context of immunity of officials. Part of the Court's concern appears to have been that a skillful litigant could craft his or her allegations as encompassing jus cogens solely to negate State immunity, thereby dragging the State into national courts even if the allegations are eventually proved to be spurious. ${ }^{88}$ That same problem presumably exists in the context of foreign officials; indeed, the problem is aggravated if during the pendency of the national proceedings the foreign official is incarcerated. Some judges in national courts have favored a denial of immunity in the face of grave allegations, ${ }^{89}$ but the practice is by no means uniform. ${ }^{90}$

Likewise, the Court's assertion that denial of state immunity was inappropriate as a remedy of "last resort' ${ }^{91}$ would also seem of relevance in contemplating the availability of immunity for foreign government officials. The Court's methodology in Jurisdictional Immunities of the State is also of interest in a more general sense; it appears the Court assumed

\footnotetext{
${ }^{86}$ ibid para 84.

${ }^{87}$ ibid paras 92-97.

${ }^{88}$ ibid para 82.

${ }^{89}$ See, e.g., Regina v Bow St Metro Stipendiary Magistrate, ex parte Pinochet (No. 3) [1999] UKHL 17, [2000] 1 AC 147, 278 (HL) (Lord Millett); Italy v. Lozano, Cass, sez un, 24 luglio 2008, n 31171, Intl L Domestic Cts [ILDC] 1805 (It 2008), available at http://www.cortedicassazione.it/Documenti/31171_Iraq.pdf (in Italian). Some precedents of this kind are actually dissents, which suggests that the purported exception to official immunity is not yet accepted. See Al-Adsani v United Kingdom App no 35763/97 (ECtHR, 21 November 2001) (Grand Chamber) (joint dissenting opinion of Judges Rozakis and Caflisch, joined by Judges Wildhaber, Costa, Cabral Barreto, and Vajić, and dissenting opinions of Judge Ferrari-Bravo and of Judge Loucaides), available at http://www.unhcr.org/refworld/docid/3fe6c7b54.html.

${ }^{90}$ See Ingrid Wuerth, 'Pinochet's Legacy Reassessed' [2012] 106 AJIL 731.

${ }^{91}$ Jurisdictional Immunities of the State (n 1), paras 98-104.
} 
the existence of immunity and then looked for an exception based on settled state practice, ${ }^{92}$ an approach that might also be warranted with respect to immunities of officials.

Second, since 2005 the Commission has been studying the obligation to extradite or prosecute (aut dedere aut judicare). With the start of the new ILC quinquennium in 2012, the Commission decided not to appoint a new special rapporteur but instead to establish a working group to consider whether and how to proceed with the topic. ${ }^{93} \mathrm{~A}$ key question for the Commission is whether there is a well-settled or emergent customary international law norm of aut dedere aut judicare and, if so, what is the content of such an obligation and to which crimes does it extend? The Commission's 1996 D raft Code of Crimes against the Peace and Security of $M$ ankind identified a possible aut dedere aut judicare obligation with respect to genocide, crimes against humanity, and war crimes, ${ }^{94}$ but at that time the Commission viewed such an obligation as only de lege ferenda.

In Questions Relating to the Obligation to Prosecute or Extradite, Belgium argued that there existed a customary international law obligation of aut dedere aut judicare, which Senegal had breached by failing to submit to prosecution or to extradite former Chadian President Hissène Habré. ${ }^{95}$ In support of its position, after prompting by a question from J udge G reenwood at the end of the first round of the hearing, ${ }^{96}$ B elgium placed before the Court certain information in support of such a customary norm, including information on the national laws of fifty-one states that exercised certain forms of universal jurisdiction. ${ }^{97}$ For jurisdictional reasons, the Court did not address this part of Belgium's claim, finding that Belgium's failure to raise this claim in

\footnotetext{
92 ibid, para 85.

93 Report of the International Law Commission, 64th Sess (n 82), para 206.

${ }^{94}$ International Law Commission, 'Draft Code of Crimes against the Peace and Security of Mankind' arts 9, 17-19, and 20, available in Report of the International Law Commission, 48th Sess, 6 May-26 July, 1996, UN Doc A/51/10; GAOR, 51st Sess, Supp No 10 (1996).

${ }^{95}$ Obligation to Extradite and Prosecute (n 19), para 1.

${ }^{96}$ Public Sitting Held on Friday, March 16, Obligation to Extradite or Prosecute (n 19), CR 2012/5 at 34, available at http://www.icj-cij.org/docket/files/144/16959.pdf.

97 Public Sitting Held on Monday, March 19, Obligation to Extradite or Prosecute (n 19), CR 2012/6 at 33-35, available at http://www.icj-cij.org/docket/files/144/17202.pdf; Supplementary Written Replies of Belgium, Obligation to Extradite or Prosecute (n 19), at 24-44 available at http://www.icjcij.org/docket/files/144/17202.pdf.
} 
its diplomatic exchanges with Senegal precluded finding that there was a 'dispute' between the two States, as was necessary to establish the Court's jurisdiction. ${ }^{98}$

Nevertheless, two of the judges addressed this issue in their separate opinions. Judge Ronny Abraham asserted that no customary norm obliged Senegal to prosecute Habré in its courts, whether for torture, war crimes, crimes against humanity, or genocide. ${ }^{99}$ He viewed Belgium's information on national laws as inadequate for various reasons, especially when used to support a customary norm related to a crime committed outside the territory of the State seeking the extradition, and when neither the alleged offender nor the victims were nationals of that State. ${ }^{100}$ For example, while Belgium had cited to French law in support of a customary norm, J udge A braham asserted that the law of his own State was either treaty-based or enacted as a matter of sovereign discretion, not due to a belief that such jurisdiction was required under international law (opinio juris). ${ }^{101}$ M oreover, Judge ad hoc Serge Sur, in his dissenting opinion, indicated that the Court's unwillingness to reach the issue on the merits was driven, inter alia, by a concern that no such customary norm existed. He asserted that the jurisdictional finding in part was due to a desire 'to avoid having to find that the customary rule invoked by Belgium did not exist, so as not to hinder its possible subsequent establishment in customary law, and thus to maintain the uncertainty surrounding this point, pending further developments. ${ }^{102}$ If that view is correct, then it may suggest that now is not the time for the Commission to attempt to codify such a norm of customary international law.

Third, the beginning of this essay discussed the enduring relevance of customary international law, and the use of treaties to inform an analysis of custom, in the Court's 2012 jurisprudence. The ways in which the Court determined the existence of customary rules and the evidence used in support of such rules are directly relevant to the Commission's current project in this area. The Commission decided in the summer of 2012 to add to its agenda the topic 'Formation and evidence of customary international law' under the stewardship of Special

\footnotetext{
${ }^{98}$ Obligation to Extradite and Prosecute (n 19), paras 53-55.

${ }^{99}$ Obligation to Extradite and Prosecute (n 19), Separate Opinion of Judge Abraham paras 21, 26-41, available at http://www.icj-cij.org/docket/files/144/17068.pdf.

100 ibid paras 36-38.

101 ibid para 39.

102 Obligation to Extradite or Prosecute (n 19), Dissenting Opinion of Judge ad hoc Sur para 18, available at http://www.icj-cij.org/docket/files/144/17082.pdf.
} 
Rapporteur Michael Wood (United Kingdom). ${ }^{103}$ The topic is not focused on the substantive rules of customary international law but on how one identifies the existence of such rules. M oreover, the Special Rapporteur intends to use the case law of the Court as a central means for proceeding with his analysis. ${ }^{104}$ No doubt the Court's 2012 jurisprudence will provide ample examples for the Commission's use in the development of this topic.

\section{Conclusion}

The decisions issued by the International Court during 2012 were certainly important for those appearing before the Court; particular issues were decided that affected specific States and persons in concrete ways. $Y$ et, as is always the case, the Court's jurisprudence has broader implications, and will not doubt affect the future disposition of disputes that arise in comparable circumstances. ${ }^{105}$ M oreover, one can discern within this jurisprudence certain broad, crosscutting themes; ones that animated the Court's jurisprudence but might be fairly said to animate international law more generally. Notwithstanding the development of treaty regimes across a broad array of international law, there remains an enduring relevance of customary international law and general principles of law as sources of international law. At the same time, when identifying rules of customary international law, there is an enduring attraction to analyzing the effects of multilateral treaties in codifying or crystalizing customary rules, rather than relying on a classic analysis of the day-to-day practice of States in conjunction with their opinio juris. The concept of jus cogens remains a powerful feature of international law, available in theory to trump a State's ability to engage in contrary treaties, yet in practice the concept seems to get little traction; certainly, violations of jus cogens have proven unable to open the door to claims before national and international tribunals. International law has increasingly become attuned to the rights of persons as against the power of States and international organizations, but the traditional processes of international law pose difficult and sometimes insurmountable hurdles to persons in effectively vindicating those rights.

\footnotetext{
${ }^{103}$ Report of the International Law Commission, 64th Sess (n 82), para 157.

${ }^{104}$ Michael Wood, Note, 'Formation and Evidence of Customary International Law' paras 18-19, UN Doc A/CN.4/653 (2012), available at http://daccess-ddsny.un.org/doc/UNDOC/GEN/N12/355/31/PDF/N1235531.pdf?OpenElement.

${ }^{105}$ See, e.g., M others of Srebrenica v N etherlands \& U nited N ations, N etherlands Supreme Court J udgment, L andelijk J urispr.N r.BW 1999, at paras. 4.3.10-4.3.12 (A pr. 13, 2012), reprinted in OUP ILDC 1760 (NL 2012) (citing to J urisdictional Immunities of the State decision).
} 
The Court's jurisprudence highlights areas of international law that are incomplete or unsatisfactory. The ICJ's role is not to legislate solutions in those areas, but the Court's decisions point the direction for changes that might be pursued, either through the development of new treaties or institutions or improvements to those that al ready exist. Thus, policy-makers would do well to consider the lessons learned from the Court's recent jurisprudence in pursuing new initiatives for the codification and progressive development of international law. 